\title{
COMMENTS
}

\section{INCENTIVES VS. NONPARTISANSHIP: THE PROSECUTORIAL DILEMMA IN AN ADVERSARY SYSTEM}

Legislatures and courts have long had problems defining the extent to which a prosecutor is permitted to have a personal interest in the outcome of a case. 1 The limits on the personal interest of other public or quasi-public officers, such as corporate directors, ${ }^{2}$ judges, ${ }^{3}$ county commissioners, ${ }^{4}$ and city mayors, ${ }^{5}$ are relatively well defined. ${ }^{6}$ The limits on the interests of prosecutors, however, defy definition, in large part because of the prosecutor's unique position in the criminal justice system. As advocates in an adversary system, prosecutors have a duty to the state to enhance the effective enforceinent of the law. ${ }^{7}$ But as officers of the court, federal and state prosecutors are subject to the due process limitations of the fiftl and fourteentli ainendments. ${ }^{8}$ Prosecu-

1. See notes 37-75 infra and accompanying text.

2. See Marsh, Are Directors Trustees?: Conflict of Interest and Corporate Morality, 22 Bus. LAW. 35, 36-43 (1966). See also Wardell v. Union Pac. R.R., 103 U.S. 651 (1880); Irving Trust Co. v. Deutsch, 73 F.2d 121 (2d Cir. 1934), cert. denied, 294 U.S. 708 (1935); Globe Woolen Co. v. Utica Gas \& Elec. Co., 224 N.Y. 483, 121 N.E. 378 (1918).

3. See Ward v. Village of Monroeville, 409 U.S. 57 (1972); Dugan v. Ohio, 277 U.S. 61 (1928); Tuney v. Ohio, 273 U.S. 510 (1927).

4. See Driscoll v. Burlington-Bristol Bridge Co., 10 N.J. Super. 545, 77 A.2d 255 (1950), aff'd, 8 N.J. 433, 86 A.2d 201, cert. denied, 344 U.S. 838 (1952); In re Application of the Bd. of Supervisors, 154 Misc. 723, 278 N.Y.S. 870 (Sullivan County Ct. 1933); In re Grade Crossing Comm'rs, 69 Misc. 23, 124 N.Y.S. 1025 (Sup. Ct. 1910), rev'd and report confirmed, 148 A.D. 412 , 132 N.Y.S. 960 (1911).

5. See cases cited in note 3 supra.

6. Courts have held, for example, that corporate directors have a fiduciary duty not to participate in a corporate decision when their individual interests might be in conflict with those of the corporation. See, e.g., Irving Trust Co. v. Deutsch, 73 F.2d 121 (2d Cir. 1934), cert. denied, 294 U.S. 708 (1935) (corporate directors profited from personal purchases of stock options that the board had refused to purchase for the corporation). Judges may have no direct pecuniary interest in the outcome of the cases they hear. Tumey v. Ohio, 273 U.S. 510, 523 (1927) (convictions overturned because the judge received fees only upon conviction). Similarly, county commissioners must be disinterested in condemnation proceedings. See, e.g., In re Application of the Bd. of Supervisors, 154 Misc. 723, 278 N.Y.S. 870 (Sullivan County Ct. 1933). City mayors may not serve as judges if they have a significant interest in increasing city revenues. Ward $v$. Village of Monroeville, 409 U.S. 57 (1972); Dugan v. Ohio, 277 U.S. 61 (1928).

7. See notes $97-111$ infra and accompanying text.

8. In Mooney v. Holohan, 294 U.S. 103, 112-13 (1935), the Supreme Court stated that "the action of prosecuting officers on behalf of the state ... may constitute state action within the 
tors therefore have a duty to criminal defendants to afford them a fair trial. 9 Many courts have stated that as a matter of public pohicy prosecutors must seek justice and not merely convictions. ${ }^{10}$

Permitting a prosecuting attorney to have a personal or financial interest in obtaining a conviction promotes zealous advocacy, but at the risk of violating the defendant's due process rights. ${ }^{11}$ It is fundamentally unfair, for example, for a prosecutor to be so motivated by personal interests that he prosecutes vigorously without regard for the possible innocence of the defendant. ${ }^{12}$ The courts and legislatures have had little success in balancing the often conflicting interests of encouraging the prosecution of crimes and affording criminal defendants due process. ${ }^{13}$

This comment defines the extent to which a public prosecutor may constitutionally be personally or financially interested in the cases he prosecutes. After reviewing an important new Supreme Court decision, ${ }^{14}$ the comment closely exainmes the contrasting interests of affording criminal defendants due process through prosecutorial neutrahity and encouraging the prosecution of crimes through the use of prosecutorial incentives. The comment concludes with proposals designed to reconcile these competing interests.

\section{Marshall V. JerRico, INC: The Dilemma of Incentives vs. NONPARTISANSHIP}

In Marshall v. Jerrico, Inc. ${ }^{15}$ the Supreme Court madvertently revealed the dileminas inherent in a system that guarantees an impartial trial yet also expects prosecutors to be aggressive. Jerrico, Inc. operated a restaurant cham im the southeastern United States. An administrator of the Employnient Standards Administration of the Department of

purview of the Fourteenth Amendment." The actions of federal prosecutors are similarly subject to the due process clause of the fifth amendment. Marshall v. Jerrico, Inc., 446 U.S. 238, 249 (1980).

9. The various guidelines given a prosecutor in deciding to prosecute reflect his duty of fairness to the accused. See ABA Project ON Standards For Criminal Justice: STANdards Relating to the Prosecution Function and the Defense Function \$ 3.9, at 92 (Approved Draft, 1971) [heremafter cited as ABA PROJECT].

10. See Brady v. Maryland, 373 U.S. 83, 87 (1962). Sce also note 69 infra and accompanying text.

11. See notes 46-61 infra and accompanying text. See Ganger v. Peyton, 379 F.2d 709, 714 (4th Cir. 1967); State v. Britton, 157 W. Va. 711, 715-16, 203 S.E.2d 462, 466 (I974) ("a prosecutor's duty to the accused is fairness").

12. Ganger v. Peyton, 379 F.2d 709 (4th Cir. 1967).

13. See Marshall v. Jerrico, Inc., 446 U.S. 238 (1980). See notes 103-32 infra and accompanying text.

14. Marshall v. Jerrico, Inc., 446 U.S. 238 (1980).

15. Id. 
Labor found that Jerrico's restaurants had committed more than 150 violations of the child labor provisions of the Fair Labor Standards Act. ${ }^{16}$ The administrator assessed substantial fines, which were reduced at a hearing before an administrative law judge. Jerrico then brought suit $\mathrm{m}$ federal district court to challenge the constitutionality of the Act's civil penalty provisions. ${ }^{17}$ Those provisions required that the sums paid to the Treasury as civil penalties for child labor violations be returned to the Employment Standards Administration as reimbursement for the costs of finding violations and assessing penaltics. ${ }^{18}$ Jerrico claimed that the provisions violated the due process clause of the fifth anendinent because they crcated an "impermissible risk and appearance of bias" on the part of the administrator. ${ }^{19}$ The opportumity for personal or institutional financial gam would, Jerrico argued, encourage the administrator to "make unduly numerous and large assessments of civil penalties."20 Jerrico argued that because the assessment of penalties is a quasi-judicial function, the imducement created by the civil penalty provisions violated the due process guarantee of neutrality in the judicial decision-making process. ${ }^{21}$

The Court held that the act of assessing penalties was not quasijudicial, but instead closely resembled a prosecutorial function. ${ }^{22}$ Moreover, the Court observed that an assessed party may obtain review

16. The pertinent child labor provisions are contained primarily in section 12 of the Fair Labor Standards Act, 29 U.S.C. § 212 (1976).

17. Fair Labor Standards Act § 16(e), 29 U.S.C. § $216(\mathrm{e})$ (1976).

18. Id.

19. 446 U.S. at 241 .

20. $I d$.

21. Brief for Appellees at 17-19, Marshall v. Jerrico, Inc., 446 U.S. 238 (1980).

22. Specifically, the Court stated:

The assistant regional administrator simply cannot be equated with the kind of decisionmakers to which the principles of Tumey and Ward have been held applicable. He is not a judge. He performs no judicial or quasi-judicial functions. He hears no witnesses and rules on no disputed factual or legal questions. The fimction of assessing a violation is akin to that of a prosecutor or civil plaintiff.

446 U.S. at 247. This holding implicitly rejected a century of state and lower court decisions that a prosecutor performs a quasi-judicial function and is therefore subject to the requirenent of coinplete neutrahity. See Ganger v. Peyton, 379 F.2d 709, 714 (4th Cir. 1967) ("The prosecuting attorney is an officer of the court, liolding a quasi judicial position"); State ex rel. Latham v. Spencer Circuit Court, 244 Ind. 552, 556, 194 N.E.2d 606, 608 (1963); Plaquemines Parish Comm'n Council v. Perez, 379 So. 2d 1373, 1376 (La. 1980); Hurd v. People, 25 Mich. 405, 415-16 (1872); Adans v. State, 202 Miss. 68, 75, 30 So. 2d 593, 596 (1947); State v. Boyce, 194 Neb. 538, 540, 233 N.W.2d 912, 913 (1975) ("his office is quasi-judicial"); Commonwealth v. Nicely $130 \mathrm{~Pa}$. 261, 270, 18 A. 737, 738 (1889) ("The district attorney is a quasi judicial officer"); Biemel v. State, 71 Wis. 444, 450,37 N.W. 244, 247 (1888) (the prosecutor holds "a position analogous to that of the judge who presides at the trial"). See also ABA Project, supra note 9, § 1.1, at 44. See text accompanying notes 55-61 infra. 
by an administrative law judge; ${ }^{23}$ because the reviewing judge can adjust or dismiss the penalties, the alleged violator is guaranteed judicial neutrahity in the final assessment of the penalty. ${ }^{24}$ The Court therefore held that the mere possibility of bias on the part of the admimistrator in assessing the penalties did not violate due process. ${ }^{25}$

According to the Court, a prosecutor is not a "judicial or quasijudicial" officer, ${ }^{26}$ and therefore is not generally subject to the strict due process neutrality requirements that the Court applied to judicial officers in Tumey $v$. Ohio ${ }^{27}$ and Ward v. Village of Monroeville. ${ }^{28}$ The Court explaimed:

Our legal system has traditionally accorded wide discretion to criminal prosecutors in the enforcement process, . . . and similar considerations have been found applicable to administrative prosecutors as well .... Prosecutors need not be entirely "neutral and detached". . . . In an adversary system, they are necessarily permitted to be zealous in their enforcement of the law. The constitutional interests in accurate finding of facts and application of law, and in preserving a fair and open process for decision, are not to the same degree implicated if it is the prosecutor, and not the judge, who is offered an incentive for securing civil penalties. The distinction between judicial and nonjudicial officers was explicitly made in Tumey, ... where the Court noted that a State legislature "inay, and often ought to, stimulate prosecutions for crime by offering to those who shall initiate and carry on such prosecutions rewards for thus acting in the interest of the state and the people."29

In dictum the Court qualified this strong language, stating that the prosecutor should serve the public interest, not his private concerns, and that there are limits to prosecutorial discretion. The Court indicated that enforcement decisions nnay not be "motivated by improper factors" or be "otherwise contrary to law." 30 Government schemes "in-

23. 446 U.S. at 241, 244; see Administrative Procedure Act \& 54, 5 U.S.C. § 554 (1976); Fair Labor Standards Act \& 16(e), 29 U.S.C. § 216(e) (1976).

24. 446 U.S. at 244.

25. Id. at $246-48$.

26. Id. at 248 .

27. 273 U.S. 510 (1927). See note 150 infra.

28. 409 U.S. 57 (1972) (a judge should be disqualified if he has an institutional interest in the outcome of the case).

29. 446 U.S. at $248-49$ (citations omitted). See note 111 infra.

30. Id. at 249. The Court cited two cases, Dunlop v. Bachowski, 421 U.S. 560, 567 n.7, $568-$ 74 (1975) and Rochester Tel. Corp. v. Umited States, 307 U.S. 125 (1939), to support this proposition. In Dunlop the Court adopted the reasoning of the court of appeals, which had stated first that "the doctrine of prosecutorial discretion should be limited to those civil cases which, like criminal prosecutions, involve the vindication of societal or governmental interest, rather than the protection of individual rights." Bachowski v. Brennan, 502 F.2d 79, 87 (3d Cir. 1974), modified sub nom. Dunlop v. Bachowski, 421 U.S. 560 (1975). Second, the court stated that "clearly defined" factors limited the prosecutorial discretion of the administrator. 502 F.2d at 88 . Yet no 
jecting a personal interest, financial or otherwise, into the enforcement process" 31 might bring "irrelevant or impermissible factors into the prosecutorial decision and in some contexts raise serious constitutional questions." 32 The Jerrico Court concluded, however, that there was no need to define precisely the limits on a prosecutor's financial or personal interest; it found that the reimbursement scheme had little influence on the administrator. ${ }^{33}$

The dictum in Jerrico reveals the prosecutor's dilemma in the adversary system. It is difficult to conceive of an incentive plan that offers a reward to a prosecutor to secure a civil or criminal penalty but does not imject an impermissible "personal interest, financial or otlierwise, into the enforcennent process." 34 Incentive plans are designed to appeal to personal interests; a prosecutor receiving a conviction fee or a portion of the civil penalty necessarily has a personal financial interest in the outcome of the case. The following two sections of this comment explore the conflicting judicial and legislative approaches to reconciling the coinpeting interests of inaintaining impartiality and providing personal incentives.

factors were clearly defined in Jerrico; moreover, Jerrico involved a criminal prosection. In Rochester Tel. Corp. the Court simply held that an enforcement decision based on undisputed facts cannot be contrary to law. 307 U.S. at 145-46.

Thus, neither of these decisions helps determime the meaning of "improper factors." Other authorities cited in Jerrico also fail to deal with motives or improper factors. See 446 U.S. at 249 n.11.

31. 446 U.S. at 249.

32. Id. at 249-50. The Court cited Bordenkircher v. Hayes, 434 U.S. 357, 365 (1978), in support of this dictum. In Bordenkircher the Supreme Court upheld a conviction even though the prosecutor, during plea negotiations, had threatened to indict the defendaut under a habitual offender statute if he did not plead guilty to the origmal, less serious charges. The Bordenkircher opmion also stated that prosecutorial discretion has "constitutional limits upon its exercise," $i d$., but did not specify the extent of those limits; it thus provided no guidelines about the meaning of "irrelevant or impermissible factors."

Jerrico also referred to 28 U.S.C. $\$ 528$ (Supp. II 1978), which directs the Attorney General to formulate regulations governing the extent of permissible prosecutorial personal interest. The Attorney General has not, however, issued any regulations pursuant to the statute. See notes 90 94 infra and accompanying text. Agam, the authority referred to by the Jerrico Court fails to help define "impermissible factors."

33. 446 U.S. at 250-52. The Court gave three reasons why the interest of the administrator was too remote to bias him. First, his salary was fixed by law and would not be affected by the number or amount of penalties he imposed. Second, his employer had no real interest in the sums collected because the total amount of fines imposed in each past year did not even equal the amount returned to the Treasury by the Employment Standards Administration in that year. Third, the agency had allocated the money to the regional offices only once, and did so based on the expenses imcurred in imvestigating and prosecuting child labor violations, not on the amounts of penalties collected.

34. 446 U.S. at 249. 


\section{Serving the Public Interests: Justice as the Goal of The Public Prosecutor}

\section{A. The Rationale for Limiting Prosecutors' Personal Interests.}

Although criminal and administrative prosecutors have traditionally been accorded wide discretion, ${ }^{35}$ enforcement decisions influenced by iniproper factors are not immune from judicial scrutiny. ${ }^{36}$ Few courts or legislatures, however, have extensively indicated what factors influencing the decision to prosecute are improper. ${ }^{37}$ Generally courts hold that a significant personal interest in the outcome of a case disqualifies a prosecutor from the case, ${ }^{38}$ but a court's decision to disqualify usually depends on the facts of the particular case. Moreover, courts and legislatures have in general failed to articulate the precise legal grounds for disqualifying a prosecutor from a case in which he has some personal interest. For example, in Berger $v$. United States ${ }^{39}$ the Supreme Court relied on both public policy and constitutional grounds to justify disqualification of the prosecutor. The United States attorney im Berger had been ruthless and unrelentimg in his efforts to convict the defendant, "overstepp[ing] the bounds of that propriety and fairness which should characterize the conduct of such an officer in the prosecution of a criminal offense." 40 The Court provided no clear statutory or constitutional standard for determining when a prosecutor's conduct or interests require that he be disqualified. ${ }^{41}$ Rather, the Court merely stated that the "average jury . . . has confidence" that a prosecuting attorney will not make "improper suggestions, insinuations, . . . [or] assertions of personal knowledge." 42 The Court also stated that

35. See id. at 248; Linda R.S. v. Richard D., 410 U.S. 614 (1973); Vaca v. Sipes, 386 U.S. 171, 182 (1967); Moog Indus. v. FTC, 355 U.S. 411 , 414 (1958). See generally 2 K. DAVIS, ADMINISTRATIVE LAW TREatise 215-56 (2d ed. 1979).

36. See notes 76-87 infra and accompanying text.

37. See Marshall v. Jerrico, Inc., 446 U.S. 238 (1980); 28 U.S.C. $\$ 528$ (Supp. II 1978). Sce note 63 infra.

38. See notes 76-87 infra and accompanying text.

39. 295 U.S. 78 (1935).

40. Id. at 84 .

41. The Court merely stated:

The United States Attorney is the representative not of an ordinary party to a controversy, but of a sovereignty whose obligation to govern inpartially is as compelling as its obligation to govern at all; and whose interest, therefore, in a criminal prosecution is not that it shall win a case, but that justice shall be done. As sucl, lie is in a peculiar and very definite sense the servant of the law, the twofold aim of which is that guilt shall not escape or innocence suffer. He may prosecute with earnestness and vigor-indeed, he slould do so. But, while he may strike liard blows, he is not at liberty to strike foul ones. It is as much his duty to refrain from improper methods calculated to produce a wrongId. at 88 . ful conviction as it is to use every legitimate means to bring about a just one.

42. Id. 
misconduct by the prosecuting attorney is an "evil influence upon the jury" and should result in a declaration of mistrial.43

Implicit in the argument that the jury must not be unduly influenced is a concern for protecting a defendant's constitutional right to a trial "by an impartial jury." 44 Altliougli the Court in Berger inade no specific reference to tlie sixth amendment, the right to an impartial jury was apparently the ultimate constitutional authority for the holding. Of course the riglt to trial by an impartial jury has no application in a nonjury trial. Nor would this impartial-jury rationale disqualify a prosecutor on the basis of bias alone. Absent some otlier grounds for disqualification, a biased prosecutor in a nonjury trial could therefore use his influence to imtimidate witnesses and to influence the judge improperly. And even in jury cases, the prejudiced prosecutor would not be disqualified until he overtly misliandled the case. ${ }^{45}$

A second possible constitutional rationale for limiting prosecutors' personal interests was proposed by the Court of Appeals for the Fourth Circuit in Ganger v. Peyton. ${ }^{46}$ In Ganger the state's attorney prosecuted the case while representing the accused's wife in a divorce proceeding based upon the same alleged assault. The court invahidated the conviction on the ground that the prosecutor's dual representation denied the defendant due process. The court quoted from the Supreme Court's decision in Mooney v. Holohan:47 "That requirement [of due process], in safeguarding the liberty of the citizen against deprivation through the action of the state, embodies the fundamental conceptions of justice which lie at the base of our civil and political institutions."48 The Ganger court also cited Tumey v. Ohio ${ }^{49}$ in which the Supreme Court leeld that criminal defendants' fifth and fourteenth amendment due

43. Id. at 85 .

44. See U.S. ConsT. amend. VI: ("In all criminal prosecutions, the accused shall enjoy the right to a speedy and public trial, by an impartial jury ....). Other Supreme Court decisions interpreting the sixth amendment "impartial jury" guarantee have not referred to the effect of the prosecutor on the partiality of the jury. They have concentrated imstead on the effect of the jurors' personal backgrounds on the verdict. See Huffman v. Florida, 435 U.S. 1014 (1978) (racial composition of the jury); Taylor v. Louisiana, 419 U.S. 522 (1975) (sexual composition of the jury); Dennis v. United States, 339 U.S. 162 (1950) (employment composition of the jury).

45. Many cases, on the other hand, have held that the bias alone is sufficient to disqualify the prosecutor. See, e.g., People v. Superior Court, 19 Cal. 3d 255, 561 P.2d 1164, 137 Cal. Rptr. 476 (1977); State ex rel. Latham v. Spencer Circuit Court, 244 Ind. 552, 194 N.E.2d 606 (1963); May v. Commonwealth, 285 S.W.2d 160 (Ky. 1955); State v. Melerine, 236 La. 881, 109 So. 2d 454 (1959); State v. Jones, 306 Mo. 437, 268 S.W. 83 (1924); State v. Boyce, 194 Neb. 538, 233 N.W.2d 912 (1975).

46. 379 F.2d 709 (4th Cir. 1967).

47. 294 U.S. 103 (1935).

48. 379 F.2d at 714 (quoting 294 U.S. at 112).

49. 273 U.S. 510 (1927). 
process rights are violated if judicial and quasi-judicial officials have a personal interest in the cases they try. ${ }^{50}$ Equating a prosecuting attorney with a quasi-judicial officer, ${ }^{51}$ the court of appeals concluded that the prosecutor's dual representation of the state and the accused's wife "violates the requirement of fundamental fairness assured by the Due Process Clause of the Fourteenth Amendment."52

The fundamental-fairness rationale for disqualifying prosecutors would apply to more situations than the impartial-jury rationale would. First, it would disqualify the vindictive prosecutor from nonjury trials. Second, it would disquahify a prosecutor when his personal interests created an appearance of injustice even though they did not affect the jury. Disqualification in this second situation is important given the Supreme Court's acknowledgement that "justice must satisfy the appearance of justice" 53 in order to "generat[e] the feeling, so important to a popular government, that justice has been done." 54

Arguably, the specific holding in the Ganger ${ }^{55}$ decision is of little precedential value because Marshall $v$. Jerrico, Inc. ${ }^{56}$ specifically stated that prosecutors do not perform quasi-judicial functions. ${ }^{57}$ This dictum in Jerrico, however, tends to ignore the Court's language in Imbler $v$. Pachtman ${ }^{58}$ that the discretionary judgment of a prosecutor may be functionally compared to that of a judge. ${ }^{59}$ Imbler held that a prosecutor in performing his discretionary duties is entitled to the same absolute immunity as a judge. The constitutional rationale that the Ganger court employed, however, was not specifically discredited by the Jerrico Court. In fact, the Court acknowledged in Jerrico that a financially-motivated prosecutor could be prompted by his personal interests to act in a manner that would raise "serious constitutional questions."60 Though the prosecutor is not a judicial officer, his conduct and discretion in enforceinent decisions and prosecutions "undoubt-

50. Id. at 523 .

51. The impact of the contrary treatment of prosecutors in Jerrico is discussed in the text accompanying notes 55.61 infra.

52. 379 F.2d at 714. See also State v. Britton, 157 W. Va. 7II, 715-16, 203 S.E.2d 462, 466 (1974) ("a prosecutor's duty to the accused is fairness").

53. Offutt v. United States, 348 U.S. 11, 14 (1954) (a judge was disqualified from presiding at contempt proceedings concerning an accused who had allegedly reviled him).

54. Joimt Anti-Fascist Comin. v. McGrath, 34I U.S. 123, 172 (1951) (Frankfurter, J., concurring).

55. See notes $46-52$ supra and accompanying text.

56. 446 U.S. 238 (1980).

57. Id. at $247-48$.

58. 424 U.S. 409 (1976).

59. Id. at $422-23$ \& n.20.

60. 446 U.S. at 250. 
edly [have] constitutional limits upon [their] exercise."61 These limits could be interpreted as those necessary to preserve the sense of fairness in the trial process.

A third constitutional rationale for limiting the personal interests of prosecutors is found in a footnote in Jerrico. In refusing to define the limits on a prosecutor's personal or financial interest, the Court noted that "[i]n particular, we need not say whether different considerations might be held to apply if the alleged biasing influence contributed to prosecutions against particular persons, rather than to a general zealousness in the enforceinent process."62 This footnote implies that the rationale for limiting personal interests is to prevent discriminatory and arbitrary enforcement of the law. In Oyler v. Boles ${ }^{63}$ the Court employed similar reasoning, stating that "the conscious exercise of some selectivity in enforcement is not in itself a federal constitutional violation" as long as "the selection was [not] deliberately based upon an unjustifiable standard such as race, religion, or other arbitrary classification."64

This equal-protection rationale may be as broad in coverage as the fundamental-fairness rationale. It would justify the reversal of convictions against persons or groups prosecuted vindictively. ${ }^{65}$ It would also justify the disqualification of a prosecutor with personal interests in a case. A prosecutor is likely to conduct a case in which he has a significant personal interest differently from a case in which lie has no interest. The equal protection clause, however, prohibits the government froin treatimg citizens differently unless there is a rational relationship between the differential treatment and a permissible government objective. ${ }^{66}$ Serving the prosecutor's personal imterests is clearly not a permissible government objective. ${ }^{67}$

61. Bordenkircher v. Hayes, 434 U.S. 357, 365 (1978).

62. 446 U.S. at 250 n.12.

63. 368 U.S. $448(1961)$.

64. 368 U.S. at 456, quoted in Bordenkircher v. Hayes, 434 U.S. 357, 364 (1978).

65. See, e.g., Bordenkircher v. Hayes, 434 U.S. 357, 366-68 (1978) (Blackmun, J., dissenting) (vindictiveness against a particular defendant can disqualify the prosecutor or invalidate the conviction); United States v. Andrews, 633 F.2d 449 (6th Cir. 1980) (en banc); United States v. Velsicol Chem. Corp., 498 F. Supp. 1255 (D.D.C. 1980).

66. See Massachusetts Bd. of Retirement v. Murgia, 427 U.S. 307, 314 (1976) (per curiam); Railway Express Agency v. New York, 336 U.S. 106, 110 (1949); Lindsley v. Natural Carbonic Gas Co., 220 U.S. 61 (1911). The government objective inust, liowever, be permissible. See, e.g., Rochin v. California, 342 U.S. 165, $172-73$ (1952); Lochner v. New York, 198 U.S. 45, 53-56 (1905).

67. In Lochner v. New York, 198 U.S. 45, 53 (1905), the Supreune Court referred to the health, safety, morals, and general welfare of the public as the only permissible exercises of the police power. 
A fourth rationale for disqualifying a prosecutor with a personal interest in a case derives from a common-law approach recognized, though not rehed on, by the Supreme Court in Berger v. United States. ${ }^{68}$ Under this approach, a prosecuting attorney's conduct inay not, as a natter of public pohicy, overstep the bounds of propriety. Courts following this approach have monitored prosecutorial conduct to ensure that the public interest in promoting justice is served.69 The Louisiana Supreme Court in State v. Marcotte ${ }^{70}$ summarized the principle:

[W] hen the district attorney is personally interested in gaining a conviction, his interest is adverse to that of the State, as the State demands no victinus, seeking equal and inpartial justice only, it being just as much the duty of the prosecution to see that no innocent man suffers as it is to see that no guilty one escapes. ${ }^{71}$

Courts articulatimg this rationale have required disqualification both for prosecutorial bias or vindictiveness and for financial interest in the outcome of a case. ${ }^{72}$

The decision to disqualify can best be justified by employing all four of the preceding rationales. As a matter of public policy, a prosecutor, who represents the state, should be expected to serve the public interest. If his personal interest in the outcome of a case conflicts with the public's interest in justice, he must be disqualified; if there is a conviction, it must be overturned. This conclusion is further justified by the likelihood that a biased prosecutor will violate a criminal defendant's due process rights. Personal interest by the prosecutor might, for example, lead to misconduct that could influence a jury and interfere

68. 295 U.S. 78, 88 (1935). See note 41 supra. The Berger Court overturned the conviction because the prosecutor's improper actions might have poisoned the jury's perspective. 295 U.S. at 85.

69. See State ex rel. Latham v. Spencer Circuit Court, 244 lnd. 552, 556, 194 N.E.2d 606, 608 (1963); State v. Cox, 246 La. 748, 763, 167 So. 2d 352, 358 (1964); State v. Osborne, 54 Or. 289, 296, 103 P. 62, 65 (1909); State v. Montgomery, 56 Wash. 443, 445-46, 105 P. 1035, 1036 (1909); State v. Britton, 157 W. Va. 711, 715-16, 203 S.E.2d 462, 466 (1974). See also People v. Superior Court, 19 Cal. 3d 255, 266, 561 P.2d 1164, 1172, 137 Cal. Rptr. 476, 484 (1977); ABA CANONS OF Professional Ethics Nos. 5, 7; ABA Project, supra note 9, § 1.1, at 43-44. Accord, ABA Comm. on Professional Ethics, Opinions, No. 150 (1936).

70. 229 La. 539,86 So. $2 d 186$ (1956).

71. Id. at 546,86 So. $2 \mathrm{~d}$ at 188 . Justice McCaleb, who wrote this statement, was actually summing up the opinion in State v. Tate, 185 La. 1006, 171 So. 108 (1936). Justice McCalcb indicated in a footnote that he was not in accord with the Tate decision, 229 La. at $545 \mathrm{n} .1$., 86 So. $2 \mathrm{~d}$ at $188 \mathrm{n} .1$; nevertheless, he followed the Tate decision because the prosecution had not attacked its correctness. Since Marcotte, the decision in Tate has been upheld by the Louisiana Supreme Court. See Plaquemmes Parish Comm'n Council v. Perez, 379 So. 2d 1373, 1376-77 (La. 1980); State v. Cox, 246 La. 748, 763, 167 So. 2d 352, 358 (1964).

72. See note 69 supra. The courts have also overturned convictions obtained in violation of this policy. 
with its role as an impartial fact-finder. ${ }^{73}$ Similarly, prosecutorial bias may impugn the general fairness of the trial or result in the singling out of the defendant for prosecution on arbitrary grounds. ${ }^{74}$ In any event, prosecutorial misconduct removes the appearance of justice and fairness required for due process. ${ }^{75}$

\section{B. The Clear Limits on a Prosecutor's Personal Interests.}

1. Case Law. The rationales that courts have employed in limiting a prosecutor's personal interests have established some clear guidelines for disqualification. First, a prosecutor is disqualified from prosecuting a defendant toward whom the prosecutor has feelings of animosity or hostility. ${ }^{76}$ This is generally the case when the prosecutor or a close relative was the victim of the alleged crime. ${ }^{77}$ For example, a prosecuting attorney who was in a collision with the defendant may not prosecute him for driving while under the influence of alcohol. ${ }^{78}$ Courts have also required disqualification when the prosecutor's dislike for the defendant leads to unfair treatinent of him.79

Second, recusal or disqualification is mandated if the prosecutor or a member of his office has a close relationship with the accused. ${ }^{80} \mathrm{~A}$ friendship $^{81}$ or a counsel-chent relationship ${ }^{82}$ nay constitute such a re-

73. See notes $39-45$ supra and accoinpanying text.

74. See notes 46-67 supra and accompanying text.

75. See notes 46-54 supra and accompanying text.

76. People v. Superior Court, 19 Cal. 3d 255, 561 P.2d 1164, 137 Cal. Rptr. 476 (1977); State ex rel. Latham v. Spencer Circuit Court, 244 Ind. 552, 194 N.E.2d 606 (1963); May v. Commonwealth, 285 S.W.2d 160 (Ky. 1955); State v. Melerine, 236 La. 881, 109 So. 2 d 454 (1959); State v. Jones, 306 Mo. 437, 268 S.W. 83 (1924); State v. Boyce, 194 Neb. 538, 233 N.W.2d 912 (1975).

77. People v. Superior Court, 19 Cal. 3d 255, 561 P.2d 1164, 137 Cal. Rptr. 476 (1977) (the son of a member of the prosecutor's staff was the victim); May v. Cominonwealth, 285 S.W.2d 160 (Ky. 1955) (the prosecutor was the victim of an assault); State v. Cox, 246 La. 748, 167 So. 2d 352 (1964) (the prosecutor was defamed); State v. Boyce, 194 Neb. 538, 23 N.W.2d 912 (1975); People v. Krstovich, 72 Misc. 2d 90, 338 N.Y.S.2d 132 (Greene County Ct. 1972). But see Benton v. State, 245 Ala. 625 , 18 So. $2 d 428$ (1944) (the prosecutor was not disqualified even though the murder victim was his uncle).

78. State v. Jones, 306 Mo. 437, 268 S.W. 83 (1924).

79. See, e.g., State ex rel. Latham v. Spencer Circuit Court, 244 Ind. 552, 194 N.E.2d 606 (1963).

80. See State v. Bell, 84 Idaho 153, 370 P.2d 508 (1962); State ex rel. Williams v. Ellis, 184 Ind. 307, 112 N.E. 98 (1916).

81. See State v. Bell, 84 Idaho 153, 370 P.2d 508 (1962).

82. See, eg., Martin v. United States, 335 F.2d 945 (9th Cir. 1964); Young v. State, 177 So. $2 d$ 345 (Fla. Dist. Ct. App. 1965); People v. Kester, 33 Ill. App. 3d 262, 337 N.E.2d 44 (1975), aff d, 66 IIl. 2d 162, 361 N.E.2d 569 (1977); State v. Boyd, 560 S.W.2d 296 (Mo. Ct. App. I977); People v. Clement, 278 A.D. 1040, 106 N.Y.S.2d 812 (1951); People v. Schrager, 74 Misc. 2d 833, 346 N.Y.S.2d 101 (Sup. Ct. 1973). See generally ABA Canons of Professional Ethics No. 6; Annot., 31 A.L.R.3d 953, 963-78 (1970). 
lationship and can disqualify the prosecutor's entire office. ${ }^{83}$ Many courts automatically disquahify the prosecutor if he ever represented the accused as a private attorney, regardless of what information he may have learned or feelings he inay have developed. ${ }^{84} \mathrm{~A}$ staff member's prior representation of the accused inay also serve to disqualify the prosecutor's office. ${ }^{85}$ The existence of information actually obtained and shared by the attorney with the office, rather than the liarbormg of any personal feelings, is generally the factor that deterinines whether disqualification is required. ${ }^{86}$ Third, except under exceptional circumstances, a court will not allow a prosecuting attorney who is a material witness in the state's case to testify on behalf of the state without witlidrawing froin the prosecution of the case. ${ }^{87}$ These three restrictions on the possible personal interests of the prosecutor are well accepted. There is not, however, a consensus anong the courts about whether the prosecutor should be disqualified if he lias a direct financial interest in a case. ${ }^{88}$

2. Statutory Law. With the exception of the counsel-client relationship restriction, ${ }^{89}$ the guidelines for a prosecutor's disqualification have generally been established through judicial decisions rather than by legislation. One exception to the general legislative silence in this area is Congress's enactment in 1978 of section 103 of the Ethics in Government Act, 90 which was intended to codify the principle of

83. State v. Chambers, 86 N.M. 383, 524 P.2d 999 (Ct. App.), cert. denied, 86 N.M. 372, 524 P.2d 988 (1974). If the entire office is disqualified, a special prosecutor may be appointed to prosecute the case.

84. See, e.g., People v. Gerold, 265 Ill. 448, 107 N.E. 165 (1914); Perfect v. State, 197 Ind. 401, 141 N.E. 52 (1923); People v. Clement, 278 A.D. 1040, 106 N.Y.S.2d 812 (1951); Thoreson v. State, 69 Okla. Crim. 128, 100 P.2d 896 (1940); Garrett v. State, 94 Tex. Crim. 556, 252 S.W. 527 (1922).

85. Younger v. Superior Court, 77 Cal. App. 3d 892, 144 Cal. Rptr. 34 (1978); State v. Burns, 322 S.W.2d 236 (Mo. 1959); State v. Chambers, 86 N.M. 383, 524 P.2d 999 (Ct. App.), cert. denied, 86 N.M. 372, 524 P.2d 988 (1974).

86. Gajewski v. United States, 321 F.2d 261 (8th Cir. 1963), cert. denied, 375 U.S. 968 (1964); State v. Lacquey, 117 Ariz. 231, 571 P.2d 1027 (1977); Cole v. Commonwealth, 553 S.W.2d 468 (Ky. 1977); State v. Bell, 346 So. 2d 1090 (La. 1977); Mattress v. State, 564 S.W.2d 678 (Tenn. Crim. App. 1977). See Annot., 3I A.L.R.3d 953, 968-73 (1970).

87. See People v. Guerrero, 47 Cal. App. 3d 441, 120 Cal. Rptr. 732 (1975); State v. Donahue, 315 So. 2 d 329 (La. 1975) (mem.). But $\mathcal{C f}$. People v. Superior Court, 84 Cal. App. 3d 491, 148 Cal. Rptr. 704 (1978) (no general disqualification of the entire district attorney's office where staff members may be called as witnesses by the defense).

88. See notes 116-32 infra and accompanying text.

89. See, e.g., IdAHo CodE § 3I-2606 (1963); ME. Rev. STat. ANN. - tit. 30, § 506 (1978); Mass. ANN. Laws cl. I2, $\$ 30$ (Michie/Law. Co-op 1980); MICH. CoMP. Laws ANN. $\$ 49.158$ (1967); Minn. Stat. ANn. \$ 388.08 (West I968); Neb. Rev. Stat. \$ 23.1206 (1943); N.D. Cent. CODE $\$ 11-16-05$ (I976).

90. Pub. L. No. 95-521, 92 Stat. 1874 (codified at 28 U.S.C. $\$ 528$ (Supp. II 1978)). 
prosecutorial neutrality. The provision directs the Attorney General to promulgate rules requiring the disqualification of any officer or employee of the Department of Justice from participation in a case "if such participation may result in a personal, financial, or political conflict of interest, or the appearance thereof." 91 The legislative history of the section shows an imtent to require the Attorney General to broaden the regulations prohibiting financial conflicts of interest to include prohibition of personal and political conflicts of interest. ${ }^{92}$ Congress believed that any conflict of interest on the part of the prosecutor would reflect adversely on the "imtegrity of the entire judicial system" if the prosecutor were allowed to handle the case. ${ }^{93}$ The Attorney General has not yet promulgated any rules in the new areas. The regulations on the financial interests of a federal attorney, lowever, are clear: if the prosecutor's performance of his duty "has or appears to have a direct and predictable effect upon a financial interest" of his or of a relative, he should be disqualified from handling the matter. ${ }^{94}$ This regulation relates only to Justice Departinent attorneys and not to attorneys representing administrative agencies; moreover, only financial interests are prohibited.

There are relatively few state statutes in this area. Most states have a statute disqualifying a prosecutor who had any type of a counsel-client relationship with the defendant in a previous or pending civil 1natter;95 many states also prohibit the public prosecutor from receiving a fee other than his salary from any individual or from the state itself. ${ }^{96}$

91. 28 U.S.C. $\$ 528$ (Supp. II 1978).

92. S. ReP. No. 170, 95th Cong., 2d Sess. 79 (1977), reprinted in [1978] U.S. CODE CoNG. \& AD. NEWS 4217, 4295.

93. Id. 62, reprinted in [1978] U.S. CODE CONG. \& AD. News 4278.

94. Justice Dep't Standards of Conduct, 28 C.F.R. \& 45.735-5 (1979). In the late 1880s the federal government enforced statutes that were designed to reward the prosecutor for convictions and therefore had a "direct and predictable effect" on his financial interests. Section 824 of the 1878 Revised Statutes of the United States rewarded the prosecutor a nuaximuin of thirty dollars for each conviction. See Act to Regulate Fees and Costs, ch. 80, $\$ 1,10$ Stat. 161 (1853). Section 825 gave the prosecutor two per cent of all tax revenues he collected. See Act to Prevent and Punish Frauds, ch. 76, § 11, 12 Stat. 741 (1863). See generally United States v. Matthew, 173 U.S. 381, 386 (1898). In 1896, however, Congress enacted a law requiring all such fees to go into the Treasury, and in 1905 Congress prohibited United States district attorneys from receiving any more fees beyond their regular salaries (except in the District of Columbia). See Appropriations Act of May 28, 1896, ch. 252, § 6, 29 Stat. 140, 179 (1896); Appropriations Act of March 3, 1905, ch. 1483, \& 1, 33 Stat. 1156, 1207 (1905).

95. See, e.g., Idaho Code § 31-2606 (1963); Me. Rev. Stat. ANn. tit. 30, § 506 (1978); Mass. ANn. Laws ch. 12, $\S 30$ (Michie/Law. Co-op 1980); MiCH. Comp. LAws ANN. $\S 49.158$ (1967); Minn. Stat. ANn. \$388.08 (West 1968); Neb. Rev. Stat. \$23.1206 (1977); N.D. Cent. CODE \& 11-16-05 (Supp. 1979).

96. See statutes cited in note 95 supra. See also R.I. GEN. LAws $\S 42-9-10$ (1977); S.C. CODE $\S 1-7-360$ (1976); Wis. Stat. AN. $\$ 59.49$ (West Supp. 1980). 
Beyond this, state statutes place no specific limitations on a prosecutor's personal interests.

\section{CONTRAST: THE INCENTIVES OR REWARDS CONCEPT}

\section{A. The Desirability of Prosecutorial Rewards.}

A number of decisions have recognized the desirability of offering incentives to prosecutors to encourage zeal and vigor in the enforceinent process. ${ }^{97}$ It is generally presuined, in light of the coinpetitiveness of the adversary system, ${ }^{98}$ that government lawyers will have some interest in winning their cases. ${ }^{99}$ The Supreine Court thus noted in Marshall v. Jerrico, Inc. ${ }^{100}$ that government prosecutors are "necessarily permitted to be zealous in their enforcement of the law"; 101 in fact, they "ought to" be rewarded for initiating and carrying on prosecutions in the public interest. ${ }^{102}$

The Supreme Court has approved certain specific incentives intended to encourage zeal in protecting the public interest. For example, in United States v. Murphy ${ }^{103}$ the Court approved a law that required a portion of a criminal penalty to be returned to the inforiner. The Court concluded that such reinubursement did not necessarily deprive the informer of his coinpetence as a witness. ${ }^{104}$ In Dorsheimer $v$. United States ${ }^{105}$ the Court specifically approved a reward system for federal tax collectors. One half of the financial penalty iniposed upon a person convicted of evading federal taxes was returned to the revenue agent who discovered the fraud. The Court found that such rewards to public officers would "stinulate and reward their zeal and industry in

97. See, e.g., Marshall v. Jerrico, Inc., 446 U.S. 238, 248-49 (1980). See notes 103-11 infra and accompanying text.

98. The adversary nature of the system is guaranteed by the requirement that the parties to a case have personal stakes in its outcoune, thus creating a "case or controversy." See Frothingham v. Mellon, 262 U.S. 447 (1927); Muskrat v. United States, 219 U.S. 346 (1911). A conflicting interest is necessary so that a court's perspective is not distorted by uninterested parties that fail to argue the issues vigorously. See Schlesinger v. Reservists Comm. to Stop the War, 418 U.S. 208, 221 (1974); Flast v. Cohen, 392 U.S. 83, 101 (1968). Even though prosecutors represent the public interest, it is therefore at least arguably desirable that they have some type of personal stake in the outcome of their cases. See generally United States v. Richardson, 418 U.S. 166 (1974); United States v. SCRAP, 412 U.S. 669 (1973); Sierra Club v. Morton, 405 U.S. 727 (1972); U.S. CoNsT. art. III, § 2; ABA CODE OF Professional ResPonsibILITY EC 7-23.

99. Marshall v. Jerrico, Inc., 446 U.S. 238, 248-49 (1980); Adams v. State, 202 Miss. 68, 75-79, 30 So. 2d 593, 596-97 (1947); State v. Osborne, 54 Or. 289, 296, 103 P. 62,65 (1909).

100. 446 U.S. 238 (1980).

101. Id. at 248.

102. Id.

103. 41 U.S. (16 Pet.) 203 (1842).

104. Id. at 209-10.

105. 74 U.S. (7 Wall.) 166 (1868). 
detecting fraudulent atteinpts to evade the payment of duties and taxes."106 Thirty years later the Court reaffirmed the value of such incentives in United States $v$. Matthews, ${ }^{107}$ in which a deputy marshal was rewarded for his participation in the arrest and conviction of a criminal. The Court wrote favorably of the "expediency of offering to public officers a reward as an incentive or stimulus for the energetic performance of public duty." 108 The Court was careful, however, to distinguish between rewards from private individuals and rewards from the government, stating that a public officer could receive only a reward authorized by "competent legislative and executive authority." 109 These three cases were decided in the 1800 s, however, when many federal einployees received their compensation largely from the fees or fines they collected rather than through the current salary system. ${ }^{110}$ In Jerrico the Court in dictum specifically approved incentive systeins for salaried public prosecutors, stating that the adversary systen assumed the propriety of prosecutorial incentives. ${ }^{111}$

The concept of incentives has led many states to enact laws that reward prosecutors based on their "effectiveness," which is usually defined in terms of number of convictions. In eiglit states the prosecutor receives conviction or prosecuting fees as additional coinpensation. The fees are either collected from the defendant as a portion of the financial penalty and then given to the prosecutor or paid to the prosecutor directly by the local government. ${ }^{12}$ The fees are graduated, witl

106. Id. at 173 .

107. 173 U.S. 381 (1899).

108. Id. at 386 .

109. Id. at 385 .

110. See, e.g., 5 U.S.C. $\$ 5332$ (Supp. II 1978). See also note 94 supra.

111. 446 U.S. at 248-49. See text accompanying note 29 supra. In so holding, the Court quoted from Tumey v. Ohio, 273 U.S. 510, 535 (1927), that states "ought to" offer incentives for those initiating pubhic prosecutions. As authority, Tumey had cited to United States v. Murphy, 41 U.S. (16 Pet.) 203 (1842), which had held only that informers, not public prosecutors, should receive rewards. Because most public prosecutors are now salaried, this oversight is particularly significant. See note 94 supra.

112. ARK. STAT. ANN. \$ 12-1707 (1979) (the prosecutor receives $\$ 5$ for each judgment, $\$ 10$ for eaclı misdemeanor conviction, and $\$ 25$ for eaclı gambling conviction); DEL. CoDE tit. 10, $\$ 8701$ (1974) (Attorney General receives $\$ 10$ for prosecuting capital crimes, and $5 \%$ on collecting forfeited bonds); FLA. STAT. ANN. $\S 351.18$ (West 1968) (repealed, effective Oct. 1, 1982) (the state attorney receives a reasonable fee for judgments against the railroad in railroad safety cases); ILL. ANN. STAT. ch. 53, $\$ 8$ (Sinith-Hurd Supp. 1980) (the prosecutor receives $\$ 30$ for serious convictions, $\$ 15$ for lesser convictions, and $\$ 25$ for each day employed in the trial of a case); LA. REv. Stat. ANN. \& 16:4 (West 1963) (the state pays \$5 to \$25 for convictions); Pa. STat. ANN. tit. 16 $\$ \S 11442-11446$ (Purdon 1956 \& Supp. 1980); Tex. Code Crim. Proc. ANN. arts. 1023-1025 (Vernon) (1979); Tex. Rev. Civ. STAT. ANN. arts. 3883, 3890 (Vernon 1966) (the county or district attorney receives $\$ 250$ for an antitrust conviction and varying amounts for other convictions based on the county and on the seriousness of the conviction); WYO. STAT. $\$ 18-3-303$ (1977) (fees to be set by county commissioners). 
larger fees paid for more serious crimes. In one state prosecutors also receive commissions on the criminal or civil penalties assessed. ${ }^{113}$ Nine states have laws imposing on the convicted defendant prosecuting fees that go into the state or county coffers. ${ }^{114}$ Thirty-four states have no prosecuting or conviction fees, though in a number of these, laws providing for such fees were only recently repealed. ${ }^{115}$

\section{B. Court Decisions About the Award of Financial Incentives to Prosecutors.}

The award of fees or commissions, because they are generally sinall, may not significantly affect the motivation of a prosecutor. ${ }^{116}$ In Bonnet v. State, ${ }^{117}$ however, a New Jersey superior court found that conviction fees im general violate public policy. The court stated that compensating prosecutors for obtaining convictions is inconsistent with the prosecutor's duty "not to convict but to see that justice is done."118

113. See Ill. ANn. Stat. ch. 53, 88 (Smith-Hurd Supp. 1980).

114. See ARK. Stat. ANN. $\$ \S 12-1707,24-116$ (1979) (felony conviction fees go to the county); GA. CODE ANN. § 24-2905(c) (Supp. 1980); IND. CODE. ANN. § 33-14-7-20 (Burns Supp. 1979); IOWA CODE ANN. \& 340.9 (West 1977) (fees go to court expense fund); Miss. CODE ANN. \& 25-39(1) (Supp. 1980); Mo. ANN. Stat. $\$ \$ 56.310,56.330$ (Vernon Supp. 1980); N.J. Stat. ANN. $\S \S 22 A: 3-2,2 A: 158-13$ (West 1971); TENN. CODE ANN. \$§ 8-21-301, 8-22-201 (1980); W. VA. CODE $\$ \$ 59-1-28,59-2-17$ (1966).

115. Many states expressly or imphedly forbid the awarding of conviction fees and commissions. See ARIZ. Const. art. 22, § 17; AlASKa STAT. § 39.27.011 (1970); IdAHo Code § 31-2606 (1963); ME. Rev. STat. tit. 30, $\$ 506$ (1978); Mass. ANN. Laws ch. 12, $\$ 30$ (Michie/Law. Co-op 1980); Mich. Comp. Laws ANN. $\$ 49.158$ (1967); MinN. Stat. ANN. $§ 388.08$ (West 1968); Neb. Rev. Stat. § 23-1206 (1977); N.M. Stat. AnN. \& 36-1-7 (1978); N.D. Cent. Code § 11-16-05 (1976); OKLa. Stat. ANN. tit. 28, \& 101, tit. 19, $\$ 215.27$ (West 1976 \& Supp. 1978); Or. Rev. STAT. $\$ \$ 8.790,8.030$ (1979); R.I. GEN. LAwS § 42-9-10 (1977); S.C. CODE § 1-7-360 (1976); S.D. Comp. Laws ANN. § 7-16-23 (Supp. 1980) (except in child support cases, no fee allowed); UTAH Code AnN. § 17-16-19 (1973); Vt. Stat. AnN. tit. 32, § 1183 (Supp. 1980); VA. Code §§ 14.1-54, 121 (1978); WIs. Stat. ANN. \& 59.49 (West Supp. 1980). Alabama, California, Kansas, Kentucky, North Carolina, and Oklahoma have repealed the statutes imposing prosecuting or conviction fees. See 1975 Ala. Acts 2500 (repealing ALA. CodE tit. 11, § 85 (1958)); 1947 Cal. Stats. 1039 (repealing Ch. 21, 1851 Cal. Stats. 187); 1974 Kan. Sess. Laws 576 (repealing KAN. STAT. AnN. § 28-224 (1973)); $1980 \mathrm{Ky}$. Acts. 596, 730 (repealing Ky. Rev. STAT. ANN. $\$ 69.550$ (Baldwin 1979)); 1971 N.C. Sess. Laws 200 (repealing N.C. GEN. Stat. § 6-12 (1970)); 1969 Okla. Sess. Laws 254 (amending OKLA. STAT. tit. 28, \& 101 (Supp. 1968)). Colorado, Comecticut, Hawaii, Maryland, Montana, Nevada, New Hampshire, New York, Ohio, and Washington have never legislated in this area.

116. See, e.g., ARK. STAt. ANN. \$ 12-1707 (1979) (\$5 to $\$ 25$ goes to the prosecutor); ILL. ANN. Stat. ch. 53, \& 8 (Smith-Hurd Supp. 1980) (\$15 to \$30); LA. Rev. STAT. ANN. § 16:4 (West 1963) (\$5 to \$25); Tenn. Code AnN. § 8-21-301 (1980) (\$5 to \$50). But see Mo. Ann. Stat. § 56.310 (Vernon Supp. 1980) (up to $\$ 150$ for conviction and 25\% on sums collected); TEX. Code Crim. Proc. ANN. art. 1023 (Vernon 1979) (\$250 for an antitrust conviction).

117. 141 N.J. Super. 177, 357 A.2d 772 (1976).

118. Id. at 242, 357 A.2d at 809 (citations omitted). See also State v. Detroit Motors, 62 N.J. Super. 386, 391-92, 163 A.2d 227, 230-31 (1960). 
Besides articulating this public policy rationale, the court noted that if the fees were regularly increased to reflect inflation they might becoine high enough to pose constitutional problems. ${ }^{119}$ The Bonnet court did not identify the specific constitutional problems that might arise from the award of prosecution fees. Rather, the court cited three decisions ${ }^{120}$ that had inerely held that due process requires judicial neutrality. None of the cited cases involved prosecutorial partisanship.

Only two other courts have specifically addressed whether conviction fees should be permitted under the Constitution or as a matter of public policy. In Wyatt $v$. State ${ }^{121}$ a Texas court upheld in a threeparagraph opinion a state statute providing for prosecution fces. According to the court, a prosecutor did not perform a judicial function and the fees therefore did not violate the Texas Constitution. ${ }^{122}$ The court did not discuss the federal due process implications of prosecutorial partiality or the public policy arguments against such partiality. ${ }^{123}$

In People v. Peters ${ }^{124}$ an Illinois appellate court addressed the due process question and held that "the imposition of [conviction] fees is clearly constitutional." 125 The defendant in Peters did not, however, argue that prosecutorial partiality had violated his due process rights by affecting the fairness of his trial. ${ }^{126}$ Instead, he asserted that the fee arrangement, which provided for the assessment of higher prosecution fees against defendants who were convicted after plcading not guilty, denied him due process because it had a chilling effcct on his decision to plead not guilty. ${ }^{127} \mathrm{He}$ also argued that the fee arrangement denied defendants equal protection of the laws by discriminating against the poor. ${ }^{128}$ The court rejected both arguments, finding that the possibility of a $\$ 15$ fee being imposed after a conviction was not "chilling" and that the defendant, who was not poor, lacked standing to allege this violation of equal protection. ${ }^{129}$ Because the defendant in Peters failed

119. 141 N.J. Super. at 241,357 A.2d at $808-09$. The fees ranged from five to fifteen dollars.

120. The three decisions the court cited were Ward v. Village of Monroeville, 409 U.S. 57 (1972); Tumey v. Ohio, 273 U.S. 510 (1927); and State v. Chinn, 146 W. Va. 610, 121 S.E.2d 610 (1961).

121. 112 Tex. Crim. 280, 16 S.W.2d 231 (1929).

122. $I d$. at $281,16 \mathrm{~S} . \mathrm{W} .2 \mathrm{~d}$ at 232 . The relevant provision of the Texas Constitution, TEX. ConsT. art. $5, \S 11$, deals exclusively with the disquahification of judges.

123. See notes 46-61, 68-75 supra and accompanying text.

124. 32 Ill. App. 3d 1018, 337 N.E.2d 73 (1975).

125. Id. at 1020,337 N.E. $2 \mathrm{~d}$ at 75 .

126. See notes $46-54$ supra and accompanying text.

127. 32 Ill. App. 3d at 1020, 337 N.E.2d at 75 .

128. Id.

129. Id., 337 N.E.2d at 75-76. 
to make a number of due process and policy arguments ${ }^{130}$ agamst the imposition of prosecution fees, the Peters decision provides only limited support for the validity of financial incentive arrangements.

Reward systems providing for conviction fees and commissions on fines could constitute the type of scheme that, according to the Supreme Court in Marshall v. Jerrico, Inc., ${ }^{131}$ would inject "personal interest ... into the enforcement process" and thereby bring "irrelevant or impermissible factors into the prosecutorial decision and in soine contexts raise serious constitutional questions." 132 Although financial incentives are intended to provide rewards for prosecutors who ably perform their duties, they also encourage law enforcement for reasons unrelated to those that are supposed to shape decisions. The difficult problem is to reconcile the desire to encourage effective prosecution with the danger that financial incentives may compromise the fairness of trials.

\section{Proposed Guidelines or Resolutions}

Ensuring impartiality and providing prosecutorial incentives are conflicting goals im our adversary system. Although courts have almost uniformly held that a prosecutor inay not have a personal nonfinancial interest in a case, ${ }^{133}$ courts have not agreed about the propriety of per1mitting a prosecutor to have a direct financial interest in the outcome of a case. ${ }^{134}$ Some courts have found that financial incentives can be improper modes of motivation and therefore are unconstitutional or agaimst public policy. ${ }^{135}$ The three proposals that follow attempt to reconcile the advantages of prosecutorial incentives with their constitutional and public policy problems.

\section{A. Eliminate the Possibility of Personal Interest.}

The simplest approach to the dilemma might be to consider a prosecutor a quasi-judicial officer, as suggested in Ganger v. Peyton. ${ }^{136}$ Although there is language in Jerrico to the contrary, ${ }^{137}$ this language was not essential to the holding of the case and in fact contradicts a century of state and lower court holdings. ${ }^{138}$ Thus this proposal would extend

130. Four possible rationales for disqualification are discussed in notes 39-75 supra and accoinpanying text.

131. 446 U.S. 238 (1980).

132. Id. at 249-50.

133. See notes 76-87 supra and accoinpanying text.

134. See notes 97-132 supra and accoinpanying text.

135. See notes 116-20, 131-32 supra and accoinpanying text.

136. 379 F.2d 709 (4th Cir. 1967). See notes 22, 46-61 supra and acconpanying text.

137. 446 U.S. at 247.

138. See note 22 supra. 
the requirement of absolute neutrality that is imposed on judges to all public and administrative prosecutors. ${ }^{139}$ Although this approach, which "solves" the dilemma by removing the possibility of incentives, has serious drawbacks, ${ }^{140}$ there are good reasons to consider it further.

This approach would require states to repeal all statutes that provide outcome-based incentives to prosecutors. ${ }^{141}$ Prosecutors thus would receive no compensation or fees beyond their set salaries, regardless of the pleas entered by defendants or the complexity of the trial. Furthermore, Congress would, if it followed this approach, amend section 103 of the Ethics in Government Act ${ }^{142}$ to prohibit any prosecuting attorney, state, ${ }^{143}$ federal, or administrative, from participating in a case in which he is personally or financially interested. By redefining "personally" under the Act to include such factors as feelmgs of animosity, prior or current attorney-client relationships, or witnessing the crime, ${ }^{144}$ and by redefining "financially" to include any additional compensation or fee received for prosecuting or liandling a case, Congress could effectively preclude any prosecutorial incentive arrangements.

The reasons for this approacli are persuasive. Numerous lower court cases have specifically lield a prosecutor to be a quasi-judicial officer. ${ }^{145}$ If the impartiality approach of these cases were the law, the prosecutor's duty of serving justice would be unobstructed by his personal imterests. Moreover, the constitutional guarantees of an impartial jury, due process, and equal protection would be ensured ${ }^{146}$ because both the public prosecutor and the judge would operate to protect defendants' riglits.

Applying a standard of impartiality to prosecutors is sound because a significant aspect of a prosecutor's function is quasi-judicial:147 a prosecuting attorney must constantly decide when and when not to

139. Under this proposal, state and federal courts would apply to prosecutors the standard of neutrality described in Tuney v. Ohio, 273 U.S. 510 (1927), and Ward v. Village of Monroeville, 409 U.S. 57 (1972). See note 150 infra.

140. See text accompanying notes 160-61 infra.

141. See notes 112-14 supra.

142. 28 U.S.C. $\$ 528$ (Supp. II 1978). See notes $90-94$ supra and accompanying text.

143. Given the due process and equal protection arguments supporting prosecutorial neutrality, see text accompanying notes 46-67 supra, Congress would have sufficient power under the fifth clause of the fourteenth amendment to impose restrictions on state governments. See note 8 supra and accompanying text.

144. See notes 76-87 supra and accompanying text.

145. See note 22 supra. See also Imbler v. Pachtman, 424 U.S. 409, 423 n.20 (1976).

146. See notes 39-67 supra and accompanying text.

147. See, e.g., Imbler v. Pachtman, 424 U.S. 409, 422-23 \& n.20, 431 n.33 (1976). See also notes 58-59 supra and accompanying text. 
enforce the law. One survey of United States attorneys revealed, for example, that fewer than one-fourth of the complaints they received resulted in the filing of formal charges. 148 In Jerrico the Supreme Court acknowledged that "the decision to enforce or not to enforce may itself result in significant burdens on a defendant . . . , even if he is ultimately vimdicated in an adjudication." 149 Such discretion in deciding whether and how to prosecute should arguably subject the prosecutor to the same neutrality standards to which judges are subject. ${ }^{150}$ Indeed, the same standards of conduct are already applied to judges and prosecutors ni several situations. For example, the Supreme Court has disqualified judges who have held defendants in contempt from adjudicating the contempt proceedings. ${ }^{151}$ Similarly, state courts have forbidden prosecutors from prosecuting defendants who assaulted them..$^{152}$ Both judges ${ }^{153}$ and prosecutors ${ }^{154}$ have been disqualified be-

148. Frase, The Decision to File Federal Criminal Charges: A Quantitative Study of Prosecutorial Discretion, 47 U. CHI. L. Rev. 246, $251-52$ (1980).

149. 446 U.S. at 249. See generally 2 K. DAvis, supra note 35, at 215-56. Moreover, administrative prosecutors may actually assess a binding pcnalty on alleged violators, a function that is similar to a judge's duty to dctermine the amount of a penalty. This comparison, however, was rejected by the Jerrico Court. See 446 U.S. at 245-49.

150. See, e.g., Imbler v. Pachtman, 424 U.S. 409, 422-23 (1976) (absolute immunity for prosecutors based partially on the similarity of their functions to those of a judge). For example, in Tumey v. Ohio, 273 U.S. 510 (1927), the Supreme Court reversed convictions rendered by a mayor whose salary was paid i $m$ part by the fees and costs that he levied while acting in a judieial capacity. According to the Court, a procedure of compensation would be impermissible if it "might lead him not to hold the balance nice, clear and true betwecn the state and the accused." Id. at 532. A prosccutor who decides whether or not to bring a particular defendant to trial should be subject to a similar requirement. See generally Coumally v. Georgia, 429 U.S. 245 (1977) (per curiam); Ward v. Village of Monroeville, 409 U.S. 57 (1972); Chase v. City of Evanston, 172 Ill. 403, 50 N.E. 241 (1898); 2 K. Davis, Administrative Law TrEaTiSE $§ 12.03$ (1st ed. 1958). But cf. Depauw Univ. v. Brunk, 53 F.2d 647, 651 (W.D. Mo. 1931), affd on other grounds, 285 U.S. 527 (1932) (administrative tribunals need not be disinterestcd and impartial).

151. See Taylor v. Hayes, 418 U.S. 488 (1974); Mayberry v. Pennsylvania, 400 U.S. 455 (1971); Offutt v. United States, 348 U.S. 11 (1954). But see Tumey v. Ohio, 273 U.S. 510 (1927). In Tumey the Court stated that "matters of kinship, personal bias, state pohicy, rcmoteness of interest, would seem generally to be matters merely of legislative discrction." Id. at 523. This indicates that there is no constitutional prohibition on the influence of such factors on the judge. This conclusion seems contrary to the holdings in the Taylor, Mayberry, and Offutt decisions, in which the "personal bias" of the judge was considered a mattcr of constitutional (due process) importance. Judicial animosity alone, however, does not disqualify a judge unless it stems "from an extrajudicial source." United States v. Grinnel Corp., 384 U.S. 563, 583 (1966). See generally" 28 U.S.C. $\$ 144$ (1976). For example, a defendant may not claim bias or prejudice merely because the judge ruled agamst him. Berger v. United States, 255 U.S. 22, 31 (1921).

152. See note 77 supra and accompanying text.

153. See W. Clay Enterprises v. Greyhoumd Leasing \& Financial Corp., 467 F. Supp. 801 (D.P.R. 1979) (disqualifying a judge who had acted as labor counsel for the defcndent). See 28 U.S.C. $\S 455$ (b)(2) (1976) (federal judges with prior attorney-chent relationships with the accused are to be disqualified).

154. See note 82 supra. 
cause of previous or existing attorney-client relationships witlı a party. Furthermore, the Supreme Court lias implied that a prosecutor, like a judge, may not be influenced in his public decisions by the possibility of institutional gain. ${ }^{155}$ Finally, the Court has indicated that, as with a judge, direct pecuniary interest in a case can disqualify a prosecutor. ${ }^{156}$ Boards of commissioners are another quasi-judicial group whose functions are similar to those of some prosecutors and whose standards of conduct may therefore reasonably be applied in the law enforcement context. Boards of commissioners are not judges but, like prosecutors, are expected to serve the public interest. 157 Commissioners may preside over condemnation or valuation proceedings, a function analogous to the penalty assessment function of the administrator in Jerrico. ${ }^{158}$ The personal-interest standard applied to commissioners is generally one of strict neutrality. One New York court asserted that "[u]nquestionably, an interest in the [condemnation] award, however slight or remote, would disqualify the commissioner and be fatal to the award . . . "159 Given the similarities in the functions of commissioners and prosecutors, the latter arguably should also be lield to a stan-

155. In Jerrico the Court decided that the persoual interest of the prosecutor was too remote to constitute a violation of due process because, among other reasons, the presence of any institutional gam that the prosecutor inay have felt wheu he helped increase the agency's funds was nommal at best. 446 U.S. at 250; $c f$. Ward v. Village of Monroeville, 409 U.S. 57 (1972) (a judge must be disqualified if he has reason to feel a sense of institutional gain when he increases government revenues); Dugan v. Ohio, 277 U.S. 61 (1928) (because the mayor-judge had only a remote relationship to the finances of the city, the conviction was valid).

156. The Jerrico Court observed that the prosecutor's salary was fixed, regardless of his performance. 446 U.S. at 250. A direct pecuniary interest might liave disqualified the prosecutor. $C f$. Tumey v. Ohio, 273 U.S. 510 (1927) (a judge was disqualified because of direct pecuniary imterest).

157. Driscoll v. Burlington-Bristol Bridge Co., 10 N.J. Super. 545, 567, 77 A.2d 255, 265 (1950), affd, 8 N.J. 433, 86 A.2d 201, cert. denied, 344 U.S. 838 (1952).

158. See Marshall v. Jerrico, Inc., 446 U.S. 238, 242-48 (1980).

159. In re Grade Crossing Comm'rs, 69 Misc. 23, 25, 124 N.Y.S. 1025, 1028 (Sup. Ct. 1910), rev'd and report confirmed, 148 A.D. 412, 132 N.Y.S. 960 (1911). Some courts have allowed the commissioners to have slight personal interests in the outcome of the coudemnation hearings. See Chesapeake \& O. Canal Co. v. Binney, 5 F. Cas. 561 (C.C.D.C. 1830) (No. 2,645); In re Dillman, 263 Mich. 542, 248 N.W. 894 (1933) (no disqualification because a party has given an officer a dahia bulb); In re Apphication of the Bd. of Supervisors, 154 Misc. 723, 278 N.Y.S. 870 (Sullivan County Ct. 1933) (disqualification was not required, though the officer owned a newspaper that occasionally published notices for the condemning county); People ex rel. Howlett v. Mayor of Syracuse, 63 N.Y. 291 (1875). See also Note, The Disqualification of Administrative Officials, 41 Colum. L. REv. 1384 (1941). A fairly frequeut case of remoteness of interest oceurs when a board member has no personal interest in the matter in controversy but unay arguably be interested for some technical reason. Thus, interest as a trustee in the corporation whose property is being condemned has been held not to disqualify. See People ex rel. Howlett v. Mayor of Syracuse, 63 N.Y. 291 (1875). Neither did a commissioner's interest as a nominal shareholder in a party corporation disqualify him from condemnation proceedings in Chesapeake \& O. Canal Co. v. Binney, 5 F. Cas. 561 (C.C.D.C. 1830) (No. 2,645). 
dard of strict neutrality in the cases they handle. This approach would produce a consistent standard for all public officers who represent the public interest and seek justice at a hearing or trial.

There are, however, two probleins with requiring prosecutorial neutrality. First, complete impartiality would be very difficult to achieve. Personal pride and public pressure to win at trial are likely to bias a prosecutor regardless of any neutrality requirement. ${ }^{160} \mathrm{~A}$ second and more serious problem is the failure of this approach to provide incentives that encourage enforcement. The prosecutor would receive no reward for pursuing complex cases or for vigorously prosecuting cases brought to trial. Considerations of pride and reputation, of course, can sometimes sufficiently motivate a prosecutor; but more tangible incentives are often necessary. The neutrality approach ignores the compelling need ${ }^{161}$ for encouraging vigorous and effective prosecutions.

\section{B. Eliminate the Goal of Justice.}

A second solution to the dilemma of conflicting goals would be to discard the notion that the prosecutor strives for justice and to recognize that in a true adversary system the opposing parties should have adversary interests. ${ }^{162}$ The prosecutor, according to this solution, should be permitted not only to have personal reasons for winning the case, but also to have significant financial reasons for representing the public. Thus, Congress and state legislatures could properly enact laws making prosecutors' salaries contingent, in whole or in part, on obtaining convictions. The fee for a particular case could be deterinined by the seriousness of the crime ${ }^{163}$ and could be paid either by the defendant or, if he is unable to pay, by the government.

This approach would undoubtedly motivate prosecutors, and it would likely imcrease the efficiency of prosecutorial resource allocation: few prosecutors would be likely to spend time on cases that were unlikely to end in conviction. But there are disadvantages to this second proposal that significantly outweigh its positive poimts. First, even though he is a public officer, the prosecutor would have no reason to serve the public interest, rather than his own, if the two clashed. The prosecutor would be a "hired gun," undeserving of the public's trust. ${ }^{164}$

160. See, e.g., Adams v. State, 202 Miss. 68, 75-79, 30 So. 2d 593, 596-97 (1947).

161. See notes 97-111 supra and accompanying text.

162. This was basically the approach of the court in Wyatt v. State, 112 Tex. Crim. 280, 16

S.W.2d 231 (1929). See notes 121-22 supra and accompanying text.

163. See note 112 supra for examples of such fee arrangements.

164. See notes 68-72 supra and accompanying text. 
Second, a prosecutor performs some discretionary functions that are unreviewable; ${ }^{165}$ he is therefore immune from civil liability for the negligent performance of these duties. ${ }^{166}$ Pretrial decisions are particularly adjudicatory in nature. ${ }^{167}$ An incentive systein based solely on convictions would severely distort and bias the prosecutor's perspective toward conviction and thus require drastic fundamental changes in the reviewability of his pretrial decisions to preserve some sense of impartial justice in the pretrial stage.

Finally, the constitutional considerations of an impartial jury, of due process and fundamental fairness, and of equal protection would present serious obstacles to the actual implementation of a pure incentive system in the trial stage. ${ }^{168}$ The Supreme Court has specifically acknowledged the serious constitutional problems inherent in an untrammeled incentive program ${ }^{169}$ and has indicated that the prosecutor's duty to seek justice rather than win cases is of constitutional magnitude. ${ }^{170}$

\section{Equating Personal Interest with the Public Interest.}

The preceding two proposals illustrate the problems in completely eliminating either incentives or neutrality in attempting to resolve the problem of the apparently conflicting goals of the prosecutorial system. Both goals-zealous prosecution, and fairness and impartiality-are designed to serve distinct purposes. To reconcile the two goals and serve the purposes of each, the rewards offered the prosecutor should motivate him to serve the public interest in justice and to guarantee the constitutional requirements of an impartial jury, due process, and equal protection. Under this approach, a prosecutor would receive personal gain not by obtaining convictions but by ensuring that justice is done both to the accused and to society.

Any such approach must, however, resolve certain threshold problems. First, it may be difficult to devise a tangible yardstick to

165. See Newman v. United States, 382 F.2d 479 (D.C. Cir. 1967).

166. See Imbler v. Pachtman, 424 U.S. 409, 420-30 (1976).

167. Such decisions include, for example, whether and when to prosecute, whether and what to plea bargain, whether to present a case to the grand jury, whether to file an information, whether to dismiss an imdictment against particular defendants, what penalty to seek, and even whether to offer to put the accused in a drug rehabilitation program or to compensate the victim in return for a dismissal of charges. These resemble judicial functions. See notes 58-59, 147-50 supra and accompanying text.

168. See notes 39-67 supra and accompanying text.

169. See Marshall v. Jerrico, Inc., 446 U.S. 238, 249-50 (1980); Bordenkircher v. Hayes, 434 U.S. 357, 365 (1978).

170. See United States v. Agurs, 427 U.S. 97, 107-14 (1976); Brady v. Maryland, 373 U.S. 83 (1963). See also note 9 supra. 
measure the prosecutor's success in achieving the intangible goal of justice. One possible yardstick of success is the number of convictions obtained by the prosecutor, a standard some states currently employ. ${ }^{171}$ In the interest of justice, however, prosecutors should be rewarded only for just convictions. ${ }^{172}$ In addition, the prosecutor should be rewarded for other meritorious prosecutorial decisions and efforts in plea bargaining, grand jury hearings, deciding what charges to bring, accumulating evidence, and deciding whether to prosecute. The tangible standards should thus provide for evaluation of the prosecutor's performance in terıns of his success in achieving fairness in all facets of his job. ${ }^{173}$

A second problem that arises under this proposal is deciding who should judge the prosecutor's success at achieving justice. One possibility is to let the public decide in yearly elections. The prosecutor's actions would consistently be in the public eye because of the frequency of the elections; and the public, in whose interest the prosecutor acts, presumably is the best judge of its own interests. There are obvious problems, however, with this approach. The public typically knows hittle about the actual guilt or innocence of defendants, and laymen are rarely familiar with trial records or the propriety of trial tactics. Moreover, awareness of the public's vindictiveness toward a particular defendant could influence the prosecutor to prosecute ruthlessly for a conviction, not for justice.

The party charged with judging prosecutorial success must be both knowledgeable about the prosecutor's job and impartial about the facts of each case. He inust be able to view the prosecutor's perfornance from the prosecutor's perspective, so that the prosecutor's tactics and efforts can be accurately evaluated. Moreover, the reviewing party must be in a position of confidentiality with respect to the various cases handled by the prosecutor. Classified information, prosecutorial strategy (such as havimg a potential defendant turn infornant), and information given to grand juries could not be made known to outside attorneys or third parties without risking the destruction of long-term prosecutorial plans.

171. See notes 112-14 supra and accompanying text.

172. Rewarding prosecutors only for just convictions, however, would be difficult because all convictions not overturned on appeal are arguably just. An incentive system must, therefore, focus on the process of prosecution and not on the result.

173. Because so few cases are brought to trial, the prosecutor should be encouraged to do justice at all stages of his enforceenent work. See notes 148-50 supra and accompanying text. On the other hand, review of all the prosecutor's actions inay be logistically inpossible. 
The evaluating party should not be a judge, however, because of the separation-of-powers conflict that occurs when one branch of government has continous control over the compensation received by members of another branch. The Constitution recognizes a somewhat analogous separation-of-powers issue; Congress may not increase or diminish a President's salary while he is in office, ${ }^{174}$ a prohibition intended to prevent undue congressional influence on executive decisions. Similarly, judges should not have such influence over the salaries of the executive branch members who practice before them.

The preferred approach would reconcile the competing goals of the prosecutorial system while recognizing the need for a tangible and viable index of a prosecutor's success and the need for performance evaluation by a dismterested party tramed in the law. Under this proposal, Congress and the state legislatures would permit prosecutors to have only certain personal interests in their cases. This would ensure that personal imterests such as feelings of hostility, personal relationships, and counsel-chent relationships would be barred. Such legislation would help maintain the appearance of justice while eliminating personal motives that might distort the prosecutor's perspective. Moreover, Congress and the state legislatures could provide for compensation above the normal salary to prosecuting attorneys who perform a superior job in seeking justice and fairness. The United States Department of Justice Principles of Federal Prosecution, ${ }^{175}$ which sets standards for all aspects of prosecutorial discretion "with a view to providing guidance rather than to mandating results," 176 would be useful for evaluating prosecutorial performance. Under these guidelines a prosecutor is not expected to gam convictions; he is supposed to exercise his discretion in a manner consistent with justice. ${ }^{177}$ Congress and the state legislatures could require the prosecutor's superior officers to review periodically the prosecutor's actions and evaluate them under the Department of Justice standards. ${ }^{178}$ Based on the outcoine of this

174. U.S. ConST. art. II, § 1. See U.S. CoNST. art. III, § 1 (judges' salaries may not be diminished during their tenure in office).

175. U.S. Dep't of Justice, Principles of Federal Prosecution, 27 Crim. L. ReP. (BNA) 3277-92 (1980).

176. Id. 3277.

177. Moreover, the general principles enunciated by the Supreme Court could be used in any areas left unclear by the Principles of Federal Prosecution. The prosecutor would, for example, be expected to prosecute vigorously if evidence indicated guilt, to "strike hard blows . . . [not] foul ones." Berger v. United States, 295 U.S. 78, 88 (1935). It would be "as much his duty to refrain from improper methods calculated to produce a wrongful conviction as it is to use every legitimate means to bring about a just one." Id. See note 41 supra.

178. This approach is somewhat similar to the Oregon compensation statute. OR. REv. STAT. $\S 8.830$ (1979). This section reads: 
review, the superior officers would award up to a stipulated sum in addition to the prosecutor's regular salary. The attorney general could also be empowered to issue additional guidelines to clarify the prosecutor's duty.

This proposal would best reconcile the personal imterests of the prosecutor with the goal of justice. Because of the possibility of additional compensation and the requirement of periodic review, the prosecutor would be inotivated to ensure that justice is done and to avoid acting in an improper or careless maimer. The prosecutor would feel obligated to protect the constitutional interests of defendants as well as the interest of the public in justice; at the same time the prosecutor would be offered mcentives to ensure his zeal and superior job performance.

\section{CONCLUSION}

Providimg incentives to a prosecutor without imjectimg impermissible personal factors into the law enforcement process presents serious constitutional and public policy questions. Improper modes of motivation may not only offend the concept of the public prosecutor's duty, but may also violate the basic notions of fairness and justice that underlie the constitutional guarantees of an impartial jury, due process, and equal protection. ${ }^{179}$ An mcentive system must therefore reward the prosecutor not merely for convictions, but for just, fair, and vigorous enforcement in all areas of his performance. ${ }^{180}$ This comment has attempted to reconcile these conflicting goals by suggestimg that prosecutors be given incentives by their superiors charged witl periodically evaluating their performance.

Some ramifications of such a system may militate agamst its adoption. First, the state and federal governments may be unwilling to allocate the revenue needed to offer prosecutors additional compensation. Increased government spending is especially unpopular today, as is in-

Additional compensation from county for district attorney and deputies paid by state. Whenever, in the judgment of any county court or board of county commissioners, the salaries paid by the state to the district attorney, or to any deputy district attorney, are not commensurate with the character of the service performed, the county court or board of county commissioners may pay out of the funds of the county such additional amounts as will properly compensate said officers for the service performed.

The use of the county court or the board of commissioners as the judging party may not be desirable, however, because of: (1) a possible separation-of-powers conflict if the trial judge had the power to award the prosecutor additional compensation; and (2) the likely lack of expertise in trial tactics and matters of law among connty commissioners. See note 174 supra and accompanying text.

179. See Mooney v. Holohan, 294 U.S. 103, 112 (1935). See notes 39-75 supra and accompanying text.

180. Sce notes 148,167 supra and accompanying text. 
creased government regulation. Second, finding and inaintaining relatively disinterested superiors inay be difficult, especially given the realization that reviewing officers may be hesitant to evaluate harshly a prosecutor with whom they have recurring professional contact. Third, the placement of discretionary compensation authority in the hands of prosecutors' superiors may only inagnify the problem if the personal interests and prejudices of the superior enter into his compensation decision. ${ }^{181}$ Fourth, the mere possibility of a loss of job or reputation may be sufficient to motivate prosecutors to just and fair enforcement. The incentive program arguably would do little to increase zeal or fairness, and in any event any gams in these areas would be difficult to measure.

Nonetheless, the possibility of additional compensation would almost certainly attract more competent and highly motivated attorneys to the public prosecutor system, resulting in more vigorous and competent enforcement of the law. Government officials have long lainented the difficulty of keeping good attorneys in the public sector; because insufficient compensation lies at the heart of this problem, ${ }^{182}$ an incentive system offers at least a partial solution. Rewarding prosecutors for vigorous and fair enforcement of the law would be a step toward improving the system of criminal justice.

Dirk G. Christensen

181. Given the hierarchical structure of current prosecutorial offices, however, the ultimate power to allocate additional compensation rests in the hands of an elected official whose salary is fixed and who is responsible to the electorate for his discretionary decisions.

182. See, e.g., N.Y. Times, Nov. 15, 1979, § 2, at 3, col. 6. 